\title{
Lupinalbin A as the most potent estrogen receptor a- and aryl hydrocarbon receptor agonist in Eriosema laurentii de Wild. (Leguminosae)
}

Sylvin Benjamin Ateba ${ }^{1,4}$, Dieudonné Njamen ${ }^{1}$, Svjetlana Medjakovic ${ }^{2,3}$, Martin Zehl ${ }^{4}$, Hanspeter Kaehlig ${ }^{5}$, Alois Jungbauer ${ }^{2,3}$ and Liselotte Krenn ${ }^{4^{*}}$

\begin{abstract}
Background: Eriosema laurentii De Wild. (Leguminosae) is a plant used in Cameroon against infertility and gynecological or menopausal complaints. In our previous report, a methanol extract of its aerial parts was shown to exhibit estrogenic and aryl hydrocarbon receptor agonistic activities in vitro and to prevent menopausal symptoms in ovariectomized Wistar rats.

Methods: In order to determine the major estrogen receptor a (ERa) agonists in the extract, an activity-guided fractionation was performed using the ERa yeast screen. To check whether the ERa active fractions/compounds also accounted for the aryl hydrocarbon receptor (AhR) agonistic activity of the crude methanol extract, they were further tested on the AhR yeast screen.

Results: This study led to the identification of 2'-hydroxygenistein, lupinalbin A and genistein as major estrogenic principles of the extract. 2'-hydroxygenistein and lupinalbin A were, for the first time, also shown to possess an AhR agonistic activity, whereas genistein was not active in this assay. In addition, it was possible to deduce structure-activity relationships.
\end{abstract}

Conclusions: These results suggest that the identified compounds are the major active principles responsible for the estrogenic and AhR agonistic activities of the crude methanol extract of the aerial parts of Eriosema laurentii.

Keywords: Eriosema laurentii de Wild., Yeast transactivation assays, Estrogen receptor a, Aryl hydrocarbon receptor, Genistein, 2'-Hydroxygenistein, Lupinalbin A

\section{Background}

Plants from the Leguminosae family are well known for their medicinal properties and are used for different purposes in connection with women's reproductive function, bone density, cardiovascular health and cancer prevention. Their therapeutic effects are very often attributed to the estrogen-like phytoconstituents known as phytoestrogens. For instance, the health benefits of soybeans (Glycine max L.) and red clover (Trifolium pratense L.) on menopause-related health problems have frequently been ascribed to their high isoflavone content [1-3]. Phytoestrogen exposure occurs primarily

\footnotetext{
* Correspondence: liselotte.krenn@univie.ac.at

${ }^{4}$ Department of Pharmacognosy, University of Vienna, Althanstrasse 14, A-1090 Vienna, Austria

Full list of author information is available at the end of the article
}

through dietary intake of foods or food supplements [4] and these compounds display estrogenic properties due to the binding to estrogen receptors in target cells. Beside estrogen receptors, phytoestrogens can also directly or indirectly modulate a wide range of signaling pathways, including the aryl hydrocarbon receptor (AhR) $[5,6]$. Although the effect of this receptor on the reproductive physiology is not yet fully understood, studies have reported its involvement in several antiestrogenic activities [7-9].

Eriosema laurentii De Wild. (Leguminosae) is widely distributed in West and Central Africa where it is used as traditional remedy and food [10]. In Cameroon, E. laurentii preparations are used for the treatment of infertility and various gynecological and menopausal complaints. Our previous study showed that the methanol extract of 
the aerial parts of E. laurentii exhibited agonistic activities at the estrogen receptor $\alpha$ and the aryl hydrocarbon receptor in yeast transactivation assays and prevented menopause-related symptoms induced by ovariectomy in rats [11]. In addition, the safety profile of this extract indicated a broad safety margin following acute and subchronic oral administration [12]. Therefore, in order to identify the chemical constituents responsible for the observed estrogenic and AhR agonistic activities, an activity-guided fractionation was performed using the ER $\alpha$ - and AhR-yeast assays on recombinant Saccharomyces cerevisiae strains.

\section{Methods}

\section{General experimental procedures}

Solvents for extraction and fractionation (analytical grade) as well as HPLC-grade acetonitrile (Chromanorm) and methanol (LiChrosolv) were obtained from VWR International (West Chester, Pennsylvania, USA). Glacial acetic acid (Rotichrom) was purchased from Carl Roth (Karlsruhe, Germany). Genistein (HPLC quality) for the dereplication approach was purchased from Sigma-Aldrich (St. Louis, Missouri, USA).

\section{Plant material}

Aerial parts of E. laurentii were collected at July 10th, 2010 in Bazou, West Region of Cameroon. The plant was identified and authenticated by Mr. Victor Nana, botanist at the Cameroon National Herbarium, where a voucher specimen has been deposited under the number 24480/SRF/Cam.

\section{Preparation of the extract and fractionation}

The air-dried and pulverized aerial parts of E. laurentii $(2.5 \mathrm{~kg})$ were extracted with $95 \%$ methanol at room temperature ( $3 \times 5 \mathrm{~L}$ of solvent; $48 \mathrm{~h}$ per extraction). The combined solutions were concentrated by evaporation $\left(40^{\circ} \mathrm{C}\right)$ to afford $130 \mathrm{~g}$ of the methanol extract (=AEL) (Figure 1). The extract (in two portions of $60 \mathrm{~g}$, each) was subjected to vacuum liquid chromatography (column: $5 \times 50 \mathrm{~cm}$ ) on silica gel under successive elution with petroleum ether, petroleum ether- $\mathrm{CHCl}_{3}(1: 1, \mathrm{v} / \mathrm{v}), \mathrm{CHCl}_{3}$, $\mathrm{CHCl}_{3}-\mathrm{MeOH}(1: 1, \mathrm{v} / \mathrm{v}), \mathrm{MeOH}$ and $\mathrm{MeOH}-\mathrm{H}_{2} \mathrm{O}(7: 3, \mathrm{v} / \mathrm{v})$ using $2000 \mathrm{~mL}$ of each solvent. The eluates obtained from the two columns with the same solvent were pooled and evaporated to give petroleum ether (=PEAL, $0.26 \mathrm{~g}$ ), petroleum ether- $\mathrm{CHCl}_{3}$ (=PCAL, $0.53 \mathrm{~g}$ ), $\mathrm{CHCl}_{3}$ (=CAL, $1.53 \mathrm{~g}$ ), $\mathrm{CHCl}_{3}-\mathrm{MeOH}$ (=CMAL, $67.32 \mathrm{~g}$ ), $\mathrm{MeOH}$ (=MAL, $24.3 \mathrm{~g}$ ) and $\mathrm{MeOH}-\mathrm{H}_{2} \mathrm{O}$ (=MWAL, $4.8 \mathrm{~g}$ ) fractions. Sixty seven grams of the CMAL fraction, which was the only active one in estrogen receptor $\alpha$ yeast assay $(y E R \alpha)$, were further fractionated by liquid-liquid partition using petroleum ether-water $(1: 1, \mathrm{v} / \mathrm{v})$ to afford a water-soluble part (=W-CMAL, $29 \mathrm{~g})$, a petroleum ether-soluble part
(=P-CMAL, $11 \mathrm{~g}$ ) and a non-soluble part (=S-CMAL, $25 \mathrm{~g})$. The most active fraction S-CMAL (22 g) was suspended in $\mathrm{CHCl}_{3}$-isopropanol (3:2, v/v) and partitioned with an equal volume of water. The $\mathrm{CHCl}_{3}$-isopropanol fraction $(=\mathrm{Ci}, 17.7 \mathrm{~g})$ was applied to Sephadex LH-20 column chromatography $(4 \times 50 \mathrm{~cm}, 15 \mathrm{~mL} / 30 \mathrm{~min})$ and eluted with $80 \% \mathrm{MeOH}$ to yield eleven fractions (F1-F11) combined according to their TLC profile. F7 (529 mg) was further subjected to a Sephadex LH-20 column chromatography $(2 \times 50 \mathrm{~cm}, 5 \mathrm{~mL} / 20 \mathrm{~min})$ and eluted with $70 \% \mathrm{MeOH}$ to yield 8 subfractions (SF1-SF8). By crystallization, SF7 (108 mg) yielded lupinalbin A (21 $\mathrm{mg}$ ), whereas genistein was identified in SF5 using a dereplication approach by TLC and HPLC-DAD. The active fraction W-CMAL was partitioned with $n-\mathrm{BuOH}-\mathrm{H}_{2} \mathrm{O}$ $(1: 1, \mathrm{v} / \mathrm{v})$ and the $n-\mathrm{BuOH}$ soluble material $(=\mathrm{Bu}, 7.5 \mathrm{~g})$ was further chromatographed on Sephadex LH-20 $(4 \times 50 \mathrm{~cm}$; $10 \mathrm{~mL} / 30 \mathrm{~min}$ ) and eluted with $\mathrm{MeOH}-\mathrm{H}_{2} \mathrm{O}$ mixtures under increasing amounts of $\mathrm{MeOH}(40 \%$ to $80 \%)$ to yield 31 combined fractions (CF1-CF31). CF21 (1.3 g) was suspended in EtOAc and the supernatant was evaporated to yield 2' -hydroxygenistein (250 mg).

\section{Identification of the major active compounds}

The isoflavonoids lupinalbin A and 2'-hydroxygenistein were unambiguously identified by UV, MS, ${ }^{1} \mathrm{H}$ and ${ }^{13} \mathrm{C}$ NMR; genistein and other components of the extract by TLC-, HPLC- and MS-comparison with authentic material (Figure 2). HPLC-UV analysis was performed on a Shimadzu Prominence HPLC system with a Luna $5 \mu \mathrm{m} \mathrm{C18} \mathrm{(2)} 100 \AA(250 \times 4.60 \mathrm{~mm}$ I.D. $)$ column by a HPLC method previously described [11]. LC-MS was conducted on an UltiMate 3000RSLC-series system (Dionex, Germering, Germany) coupled to an HCT 3D quadrupole ion trap mass spectrometer equipped with an orthogonal ESI source (Bruker Daltonics, Bremen, Germany). HPLC separation in LC-MS experiments was carried out on a Luna $5 \mu \mathrm{m} \mathrm{C18} \mathrm{(2)} 100 \AA(250 \times 4.60 \mathrm{~mm}$ I.D.) column at $25^{\circ} \mathrm{C}$ using water (adjusted to $\mathrm{pH} 3.0$ with acetic acid) as mobile phase $\mathrm{A}$ and acetonitrile/mobile phase A 4:1 (v/v) as mobile phase B. The flow rate was 1.0 $\mathrm{mL} / \mathrm{min}$ and the following two gradient programs were used for the analysis of selected fractions and isolated compounds:

Gradient 1: 5\% B (0 min), 5\% B (5 min), 20\% B

(15 min), and 20\% B (30 min)

Gradient 2: 20\% B (0 min), 20\% B (5 min), 34\% B

(10 min), 34\% B (30 min), and 36.4\% B (37.5 min)

Each gradient was followed by a column cleaning and re-equilibration step. The eluent flow was split in a 1:4 ratio before the ESI ion source, which was operated as follows: capillary voltage: $\pm 3.7 \mathrm{kV}$, nebulizer: 26 psi $\left(\mathrm{N}_{2}\right)$, 


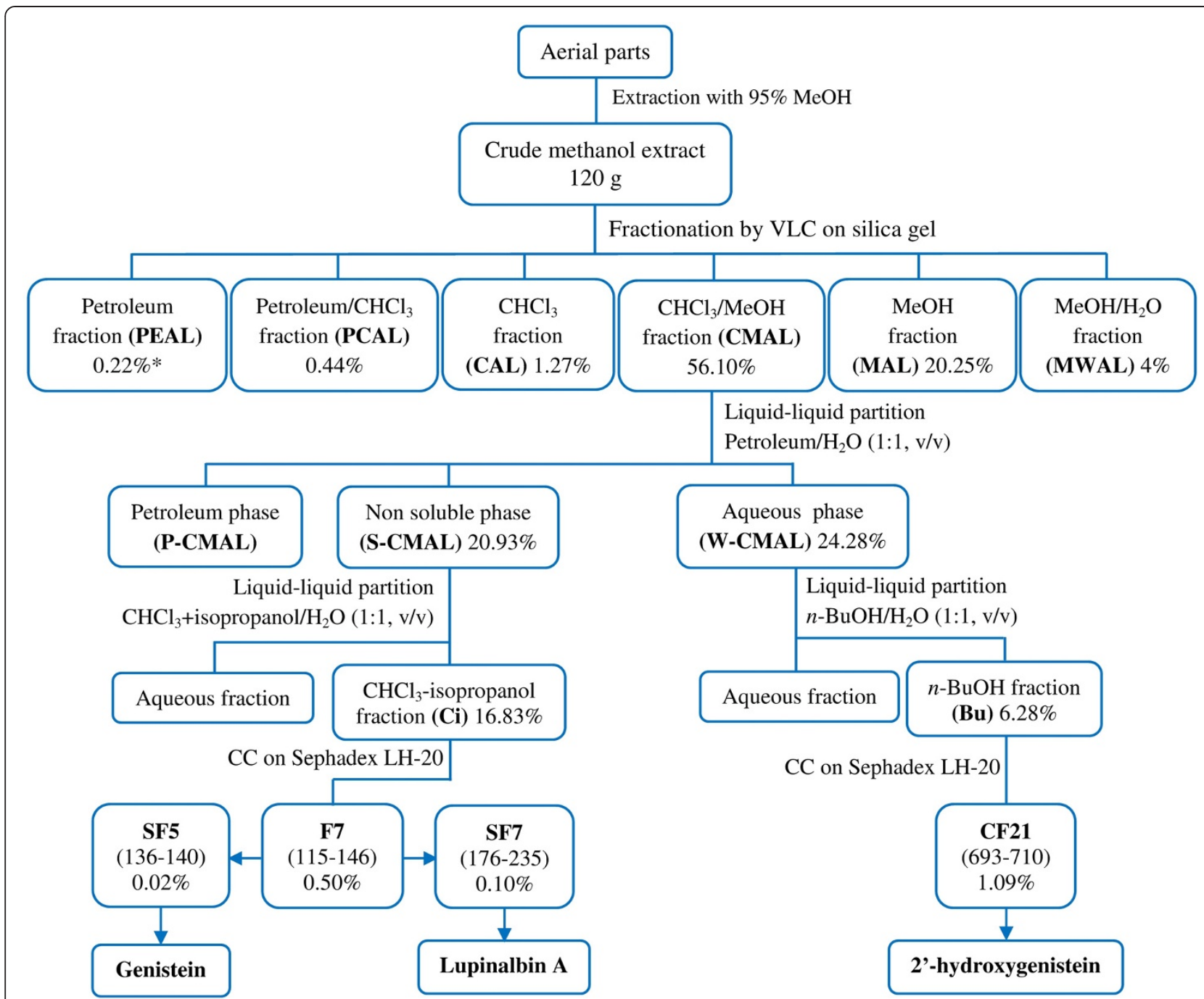

Figure 1 Scheme of extraction and fractionation of the methanol extract of the aerial parts of Eriosema laurentii. * Percent yield on dry weight basis of crude methanol extract.

dry gas flow: $9 \mathrm{~L} / \mathrm{min}\left(\mathrm{N}_{2}\right)$, and dry temperature: $340^{\circ} \mathrm{C}$. $\mathrm{MS}^{2}, \mathrm{MS}^{3}$, and $\mathrm{MS}^{4}$ spectra were obtained in an automated data-dependent acquisition mode (collision gas: $\mathrm{He}$, isolation window: $4 \mathrm{Th}$, fragmentation amplitude: $1.0 \mathrm{~V})$.

The nuclear magnetic resonance (NMR) data were recorded at 298.2 K on a Bruker Avance DRX 600 instrument operating at $600.13 \mathrm{MHz}$ for ${ }^{1} \mathrm{H}$ and 150.91 $\mathrm{MHz}$ for ${ }^{13} \mathrm{C}$, respectively. The ${ }^{1} \mathrm{H}$ - and ${ }^{13} \mathrm{C}-\mathrm{NMR}$ data of lupinalbin $\mathrm{A}$ and 2 '-hydroxygenistein are shown in Table 1 and the MS data for all three compounds are given below. The spectroscopic data were in good correlation to published data (see Table 1) [13,14].

2'-Hydroxygenistein: +ESIMS $m / z 287.0[\mathrm{M}+\mathrm{H}]^{+}$; + ESIMS $^{2}(287.0 \rightarrow) \mathrm{m} / z 271.0(8), 268.9$ (8), 259.0 (27), 244.9 (35), 230.9 (19), 216.9 (100), 202.9 (11),
189.0 (16), 175.0 (34), 161.0 (23), 153.0 (95), 149.0 (34), 137.0 (11); -ESIMS $m / z 284.9$ [M-H] ${ }^{-}$; -ESIMS ${ }^{2}$ $(284.9 \rightarrow) m / z 240.9$ (6), 216.9 (100), 198.9 (8), 174.9 (6). Lupinalbin A: + ESIMS $m / z 285.0[\mathrm{M}+\mathrm{H}]^{+} ;+$ESIMS $^{2}$ $(285.0 \rightarrow) m / z 256.9$ (100), 228.9 (23), 212.9 (10), 185.0 $(12), 173.0(6) ;+$ ESIMS $^{3}(285.0 \rightarrow 256.9 \rightarrow) \mathrm{m} / z 228.9$ (100), 173.2 (7); -ESIMS m/z 282.9 [M-H] ${ }^{-}$; -ESIMS ${ }^{2}$ $(282.9 \rightarrow) \mathrm{m} / z 265.8(8), 264.8$ (17), 254.9 (100), 238.9 (24), 236.9 (7), 226.9 (10), 214.9 (8), 210.9 (8), 172.9 $(7) ;-$ ESIMS $^{3}(282.9 \rightarrow 254.9 \rightarrow) \mathrm{m} / z 236.8(6), 226.9$ (100), 210.9 (14), 182.9 (10).

Genistein: +ESIMS $m / z 271.0[\mathrm{M}+\mathrm{H}]^{+} ;+$ESIMS $^{2}$ $(271.0 \rightarrow) m / z 253.0$ (9), 242.9 (12), 215.0 (25), 153.0 (100), 149.0 (11), 147.1 (37), 145.0 (8).

The chemical structures of these 3 major compounds are depicted in Figure 3.

For MS identification of other compounds see Table 2. 


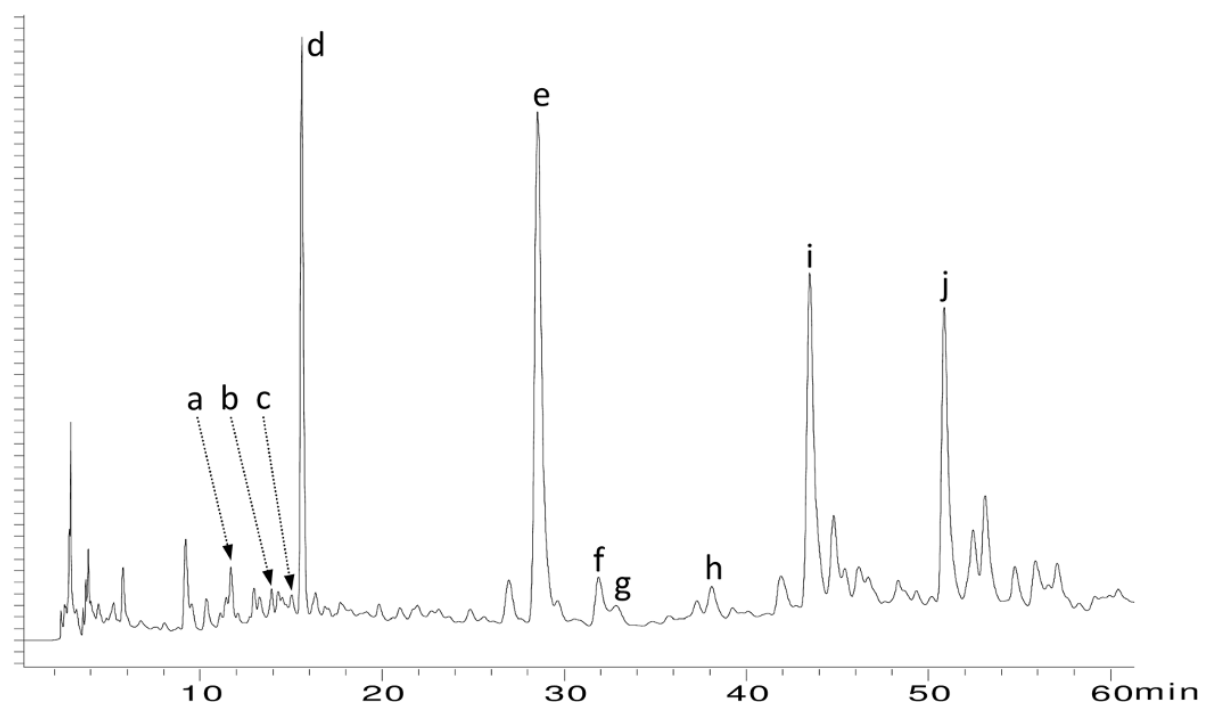

Figure 2 HPLC-DAD chromatogram $(254 \mathrm{~nm})$ of the methanol extract of aerial parts of E. laurentii. Peak letters refer to the identified compounds (see Table 2).

\section{Yeast transactivation screens}

Disodium hydrogen phosphate dihydrate $\left(\mathrm{Na}_{2} \mathrm{HPO}_{4}\right.$. $\left.2 \mathrm{H}_{2} \mathrm{O}\right)$, potassium chloride $(\mathrm{KCl})$, magnesium sulfate heptahydrate $\left(\mathrm{MgSO}_{4} \cdot 7 \mathrm{H}_{2} \mathrm{O}\right)$, sodium carbonate $\left(\mathrm{Na}_{2} \mathrm{CO}_{3}\right)$ and ammonium sulfate $\left(\left(\mathrm{NH}_{4}\right)_{2} \mathrm{SO}_{4}\right)$ were obtained from Merck (Darmstadt, Germany). Sodium dihydrogen phosphate dihydrate $\left(\mathrm{NaH}_{2} \mathrm{PO}_{4} \cdot 2 \mathrm{H}_{2} \mathrm{O}\right), N$-lauroylsarcosine (Sarkosyl), $o$-nitrophenol- $\beta$-galactopyranoside (ONPG), DL-dithiothreitol (DTT), dimethylsulfoxide (DMSO), D-(+) glucose, estradiol, $5 \alpha$-dihydroxytestosterone, genistein, progesterone, and $\beta$-naphthoflavone were purchased from Sigma-Aldrich (St. Louis, Missouri, USA). Yeast nitrogen base was obtained from Difco (Franklin Lakes, New Jersey, USA), amino acids from Serva Feinbiochemica (Heidelberg, Germany), dropout medium without tryptophan (DO-trp) from Sigma-Aldrich, and dropout supplement media without tryptophan and uracile (CSM-trp-ura) from MP Biomedicals.

LacZ-buffer was composed of $60 \mathrm{mM} \mathrm{Na} \mathrm{HPO}_{4} \cdot 2 \mathrm{H}_{2} \mathrm{O}$, $40 \mathrm{mM} \mathrm{NaH} \mathrm{PO}_{4} \cdot 2 \mathrm{H}_{2} \mathrm{O}, 10 \mathrm{mM} \mathrm{KCl}, 1 \mathrm{mM} \mathrm{MgSO}_{4}$.

Table $1{ }^{1} \mathrm{H}$ - and ${ }^{13} \mathrm{C}$-NMR data of lupinalbin $A$ and 2'-hydroxygenistein (in $\mathrm{CD}_{3} \mathrm{OD}$ ) as compared with literature [13,14]

\begin{tabular}{|c|c|c|c|c|c|c|c|}
\hline \multirow{2}{*}{ Position } & & \multicolumn{3}{|c|}{ Lupinalbin $A$} & \multicolumn{3}{|c|}{ 2'-Hydroxygenistein } \\
\hline & & ${ }^{1} \mathrm{H}(\mathrm{ppm}) \mathrm{J}_{\mathrm{H}, \mathrm{H}}(\mathrm{Hz})$ & ${ }^{13} \mathrm{C}$ (ppm) & ${ }^{13} \mathrm{C}$ (ppm) [13] & ${ }^{1} \mathrm{H}(\mathrm{ppm}) \mathrm{J}_{\mathrm{H}, \mathrm{H}}(\mathrm{Hz})$ & ${ }^{13} \mathrm{C}$ (ppm) & ${ }^{13} \mathrm{C}$ (ppm) [14] \\
\hline 2 & C & - & 166.22 & 166.2 & 7.866 & 154.78 & 155.7 \\
\hline 3 & $C$ & - & 98.65 & 99.5 & - & 122.24 & 120.8 \\
\hline 4 & $C$ & - & 180.06 & 180.0 & - & 181.59 & 180.8 \\
\hline $4 a$ & $C$ & - & 104.47 & 104.5 & - & 104.87 & 104.8 \\
\hline 5 & $C$ & - & 164.04 & 164.0 & - & 161.85 & 162.3 \\
\hline 6 & $\mathrm{CH}$ & $6.281(\mathrm{~d} 2.2)$ & 100.92 & 100.9 & $6.258(\mathrm{~d} 2.2)$ & 99.69 & 99.3 \\
\hline 7 & C & - & 165.32 & 165.2 & - & 164.54 & 164.7 \\
\hline 8 & $\mathrm{CH}$ & $6.483(\mathrm{~d} 2.2)$ & 95.83 & 95.8 & $6.335(\mathrm{~d} 2.2)$ & 94.07 & 94.0 \\
\hline $8 a$ & C & - & 156.59 & 156.6 & - & 158.04 & 158.1 \\
\hline $1^{\prime}$ & $C$ & - & 115.23 & 114.7 & - & 110.51 & 109.0 \\
\hline $2^{\prime}$ & $C$ & - & 151.95 & 151.9 & - & 158.89 & 156.8 \\
\hline $3^{\prime}$ & $\mathrm{CH}$ & 7.007 (d 2.0) & 99.51 & 98.7 & 6.424 (d 2.0) & 104.87 & 103.0 \\
\hline $4^{\prime}$ & $C$ & - & 157.81 & 157.8 & - & 156.29 & 159.0 \\
\hline $5^{\prime}$ & $\mathrm{CH}$ & $6.903(\mathrm{dd} 2.0 / 8.5)$ & 114.67 & 115.2 & $6.412(\mathrm{dd} 2.0 / 8.5)$ & 108.31 & 106.6 \\
\hline $6^{\prime}$ & $\mathrm{CH}$ & 7.780 (d 8.5) & 122.52 & 122.5 & $6.955(d$ 8.5) & 130.91 & 132.6 \\
\hline
\end{tabular}




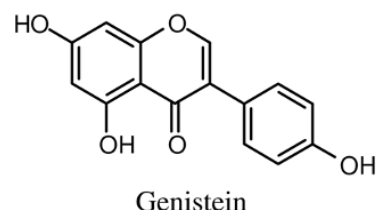

Genistein

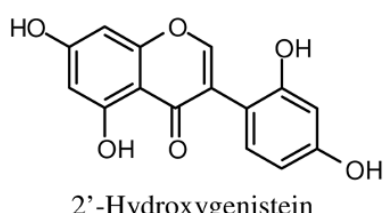

2'-Hydroxygenistein

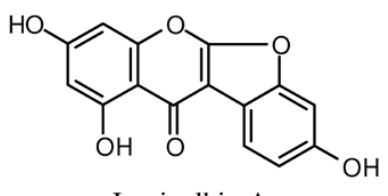

Lupinalbin A

Figure 3 Chemical structures of 2'-hydroxygenistein, genistein and lupinalbin A.

$7 \mathrm{H}_{2} \mathrm{O}$, and $1 \mathrm{mM}$ DTT. For the $Z$-sarcosyl-buffer, $0.5 \%$ $\mathrm{N}$-lauroyl-sarcosine was dissolved in LacZ-buffer with 2mM DTT.

The estrogenic and aryl hydrocarbon receptor agonistic activities were assessed using recombinant Saccharomyces cerevisiae yeast strains 188R1 and YCM3. The estrogen yeast assay is a two-plasmid system containing an expression plasmid with the human ER $\alpha$ gene and a LacZ reporter plasmid. The construct of the AhR yeast assay contains beside a LacZ reporter plasmid, the human AhR and aryl hydrocarbon receptor nuclear translocator (ARNT) genes integrated in chromosome III. Assay performance and data evaluation have been described previously $[5,15]$.

Briefly, $1 \mu \mathrm{L}$ of sample was added in $100 \mu \mathrm{L}$ of yeast culture $\left(\mathrm{OD}_{600}=0.4\right)$ and incubated at $30^{\circ} \mathrm{C}$ for $5 \mathrm{~h}$ and $17 \mathrm{~h}$ for $\mathrm{ER} \alpha$ and $\mathrm{AhR}$, respectively. After incubation cells were disintegrated by adding $150 \mu \mathrm{L} 2 \mathrm{mM}$ Z-sarcosylbuffer, the $\mathrm{OD}_{600}$ measured and the microtiter plate incubated at $30^{\circ} \mathrm{C}$ for $20 \mathrm{~min}$ for the complete disintegration. In each well, $50 \mu \mathrm{L}$ of $o$-nitrophenyl $\beta$-D-galactopyranoside (4 $\mathrm{mg} / \mathrm{mL}$ in lacZ-buffer) were added and the plate was incubated at $37^{\circ} \mathrm{C}$ till the development of yellow color. Afterwards, the reaction was stopped by adding $50 \mu \mathrm{L} 1 \mathrm{M}$ $\mathrm{Na}_{2} \mathrm{CO}_{3}$, the total reaction time noted and the absorption measured at $405 \mathrm{~nm}$ (reference wavelength $620 \mathrm{~nm}$ ).

\section{Statistical analysis}

Data are expressed as means of three independent duplicate experiments \pm standard deviation (SD) and analyzed using Student's $t$-test. Results were considered significant when $p \leq 0.05$.

\section{Results and discussion}

In order to identify the major compounds responsible for the estrogenic activity of the methanol extract of the aerial parts of $E$. laurentii, an activity-guided fractionation was performed as described in more detail above (Figure 1).

The $\mathrm{CHCl}_{3}-\mathrm{MeOH}$ fraction (CMAL) of the methanol extract from the aerial parts of E. laurentii was the only fraction that exhibited estrogenic activity. The three subfractions from CMAL (P-CMAL, S-CMAL and WCMAL) also induced a dose-dependent and significant $\beta$-galactosidase activity in estrogen receptor $\alpha$ yeast assay $(y E R \alpha)$ from $1 \mu \mathrm{g} / \mathrm{mL}(p \leq 0.05)$ compared with DMSO (Figure 4A). Fraction S-CMAL showed the strongest effect, and at the dose of $2.5 \mu \mathrm{g} / \mathrm{mL}$ this fraction exhibited a magnitude of response comparable to that of estradiol at the dose of $10 \mathrm{nM}$. In contrast, the petroleum fraction (P-CMAL) was the weakest one. S-CMAL appeared to be about 10-20 fold more potent than CMAL, whereas the weight of CMAL was only about 2.5 -fold the weight of S-CMAL. Plant extracts/ fractions contain combinations of different phytochemicals that can interact in a very complex manner leading to antagonistic/synergistic or additive mechanisms. Their fractionation can thus disrupt these molecular interactions resulting in an increase, decrease or abolishment of potency. In such a scenario, the modest potency of

Table 2 Compounds assigned in the extracts of $E$. laurentii by HPLC-DAD and HPLC/ESI-MS

\begin{tabular}{ccccll}
\hline Peak & Rt (min) & UV $\boldsymbol{\lambda}_{\max (\mathbf{M e O H})(\mathbf{n m})}$ & Molecular formula & Identification & Class \\
\hline $\mathbf{a}$ & 11.89 & $257 \mathrm{sh}, 269,349$ & $\mathrm{C}_{21} \mathrm{H}_{20} \mathrm{O}_{11}$ & Isoorientin & Flavone \\
$\mathbf{b}$ & 14.08 & 270,337 & $\mathrm{C}_{21} \mathrm{H}_{20} \mathrm{O}_{10}$ & Isovitexin & Flavone \\
$\mathbf{c}$ & 15.09 & 254,348 & $\mathrm{C}_{21} \mathrm{H}_{20} \mathrm{O}_{11}$ & Luteolin-7-O-glucoside & Flavone \\
$\mathbf{d}$ & 15.69 & $260,325 \mathrm{sh}$ & $\mathrm{C}_{21} \mathrm{H}_{20} \mathrm{O}_{10}$ & Genistin & Isoflavone \\
$\mathbf{e}$ & 28.89 & 258 & $\mathrm{C}_{15} \mathrm{H}_{10} \mathrm{O}_{6}$ & 2'-hydroxygenistein & Isoflavone \\
$\mathbf{f}$ & 32.48 & $254,266 \mathrm{sh}, 349$ & $\mathrm{C}_{15} \mathrm{H}_{10} \mathrm{O}_{6}$ & Luteolin & Flavone \\
$\mathbf{g}$ & 33.60 & 255,369 & $\mathrm{C}_{15} \mathrm{H}_{10} \mathrm{O}_{7}$ & Quercetin & Flavonol \\
$\mathbf{h}$ & 38.61 & 255,357 & $\mathrm{C}_{16} \mathrm{H}_{12} \mathrm{O}_{7}$ & Quercetin-3-O-methylether & Flavonol \\
$\mathbf{i}$ & 43.85 & 260 & $\mathrm{C}_{15} \mathrm{H}_{10} \mathrm{O}_{5}$ & Genistein & Isoflavone \\
$\mathbf{j}$ & 51.22 & $256,281,334$ & $\mathrm{C}_{15} \mathrm{H}_{8} \mathrm{O}_{6}$ & Lupinalbin A & Coumaronochromone \\
\hline
\end{tabular}




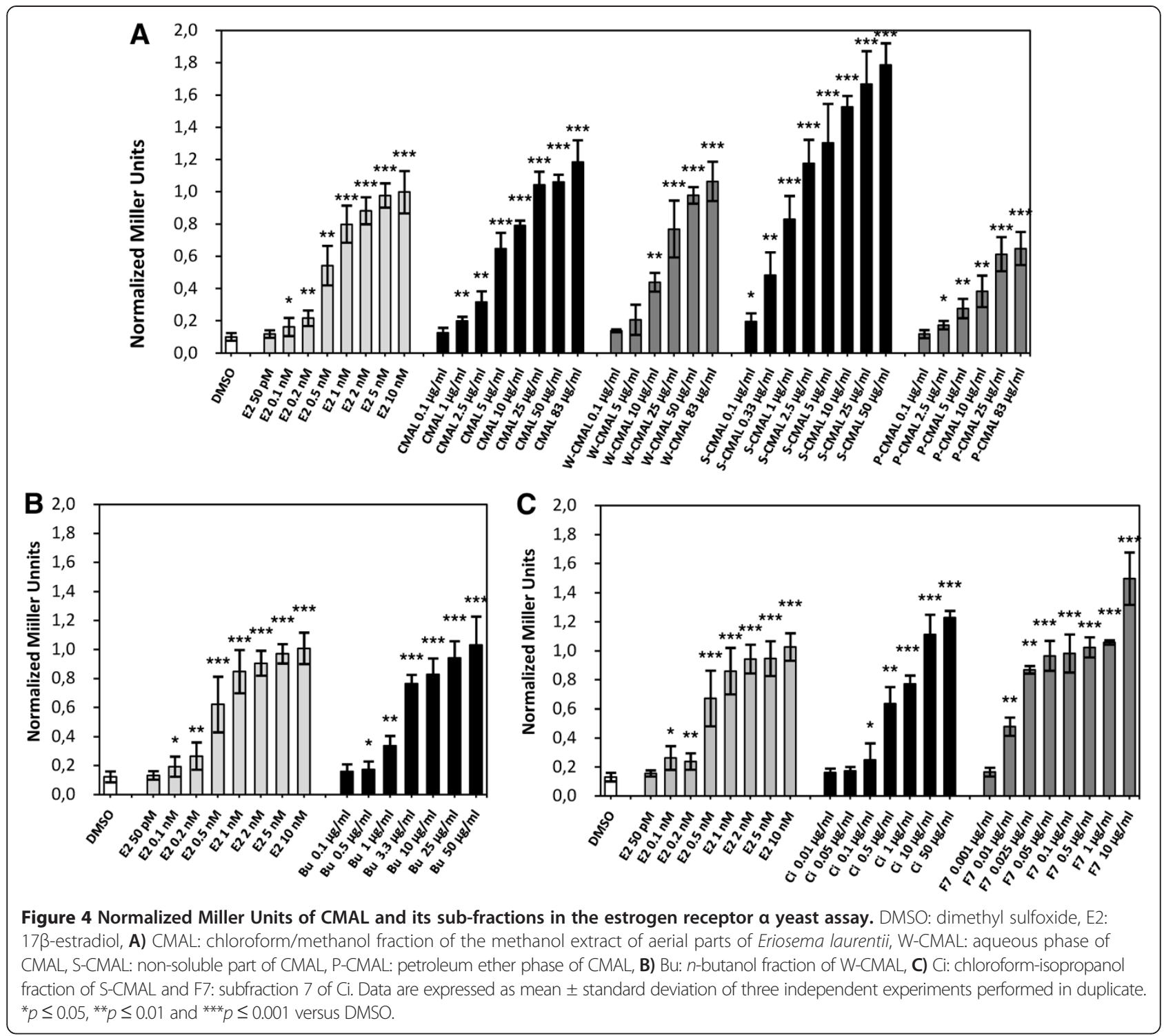

CMAL compared to its fraction S-CMAL may be related to the presence of some antagonistic interactions in CMAL. Another reason for the high activity of S-CMAL was the occurrence of genistin in the fraction. This compound was removed by partition in the aqueous fraction (see Figure 1).

Fraction $\mathrm{Bu}$ of $\mathrm{W}$-CMAL also induced a $\beta$-galactosidase activity in the ER $\alpha$ yeast assay (Figure $4 \mathrm{~B}$ ) and its fractionation yielded 2 '-hydroxygenistein $(250 \mathrm{mg}$ ) as the major component. Fraction $\mathrm{Ci}$ of S-CMAL increased the ER $\alpha$ activity in a significant and dose-dependent manner $(p \leq 0.05)$ starting from $0.1 \mu \mathrm{g} / \mathrm{mL}$. Its magnitude of activity at $1 \mu \mathrm{g} / \mathrm{mL}$ equals that of estradiol at $0.5-1 \mathrm{nM}$. Moreover, the fraction 7 of $\mathrm{Ci}$ (F7) was about a factor of ten more potent than fraction Ci (Figure 4C). From this subfraction, lupinalbin A (21 mg) was isolated. The identification of lupinalbin A and 2'-hydroxygenistein was performed by MS- and one and two-dimensional NMRexperiments. Data showed good correlation with literature (see Table 1). Genistein, one of the major constituents of E. laurentii as reported previously [11], was identified using a dereplication approach by TLC, LC-DAD and MS.

As shown in Figure 5, genistein, 2' -hydroxygenistein and lupinalbin $\mathrm{A}$ induced a dose-dependent $\beta$-galactosidase activity in the ER $\alpha$ yeast two-hybrid assay. According to the dose-response curves, the $\mathrm{EC}_{50}$ values of genistein, 2 '-hydroxygenistein and lupinalbin A were $0.32 \mu \mathrm{M}$, $6.1 \mu \mathrm{M}$ and $21.4 \mathrm{nM}$, respectively, whereas that of $17 \beta-$ estradiol was $0.27 \mathrm{nM}$. In line with these results, all three compounds displayed the maximal efficacy of the standard endogenous hormone $17 \beta$-estradiol, suggesting that they may be considered as full ER $\alpha$ agonists. On the other hand, it appears that the 2 '-hydroxylation of genistein reduced its potency by 19 -fold. In contrast, 


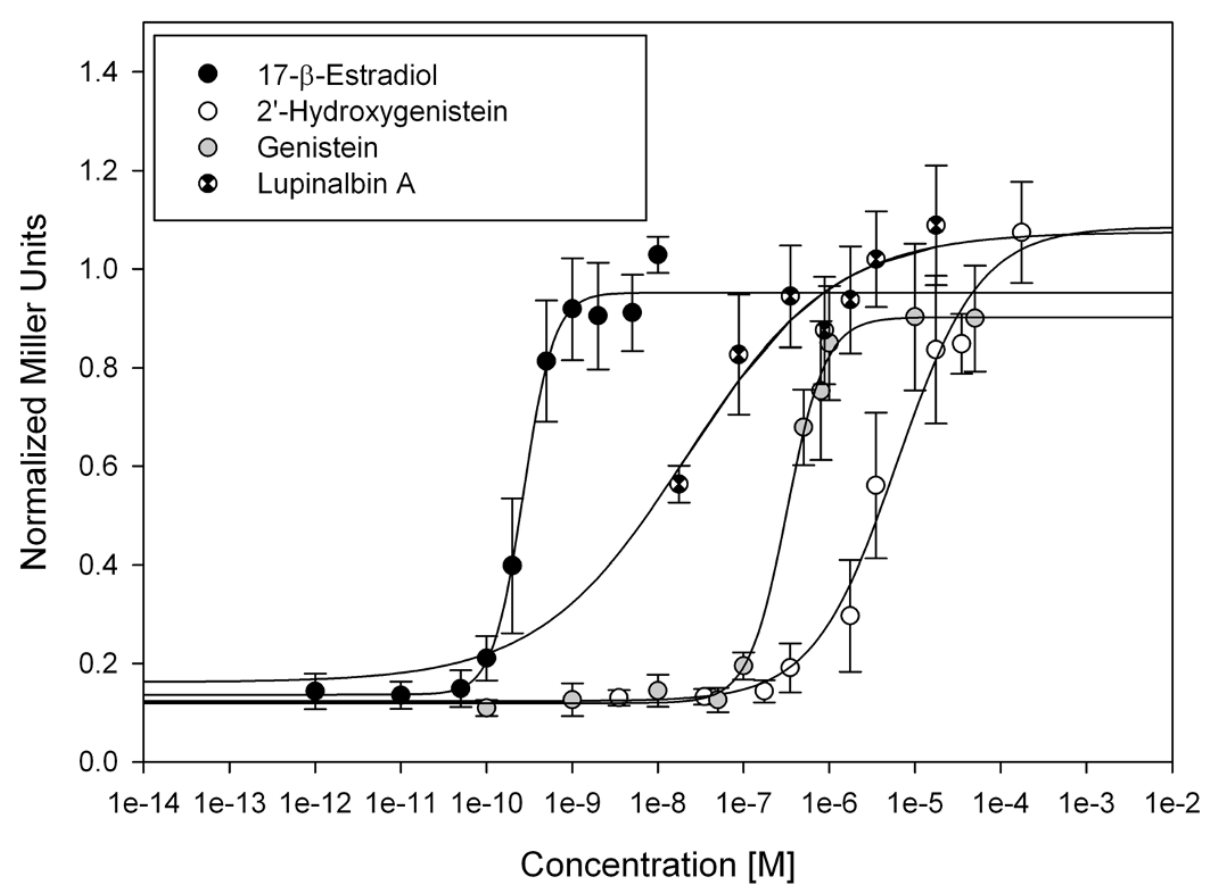

Figure 5 Dose-response curves of 2'-hydroxygenistein, lupinalbin A and genistein in the estrogen receptor a yeast assay. Mean values of at least three independent experiments performed in duplicates are shown with standard deviations.

lupinalbin A, a ring-constrained analogue of $2^{\prime}$-hydroxygenistein was approximately 15 -fold more potent than genistein.

In order to check whether the ER $\alpha$-active fractions/ compounds identified in the methanol extract of $E$. laurentii also accounted for the aryl hydrocarbon receptor (AhR) agonistic activity of the crude methanol extract, they were additionally tested on the AhR yeast screen. According to our results, the tested fractions also showed AhR agonistic properties (Figure 6). As in the ER $\alpha$ yeast screen, S-CMAL was the most potent fraction of CMAL (Figure 6A). In comparison to CMAL, it was more potent and activated the AhR already at 2.5 $\mu \mathrm{g} / \mathrm{mL}$ in the same manner $(p \leq 0.001)$ as the reference compound $\beta$-naphthoflavone at $20 \mathrm{nM}\left(=\mathrm{EC}_{50}\right)$. Fraction $\mathrm{Bu}$ (from W-CMAL) as well induced a significant and dose-dependent activity of AhR already starting from $1 \mu \mathrm{g} / \mathrm{mL}$. Its activity at $10-25 \mu \mathrm{g} / \mathrm{mL}$ equaled that of $\beta$-naphtho-flavone at $20 \mathrm{nM}$ (Figure 6B). Similarly, fraction $\mathrm{Ci}$ and its sub-fraction F7 induced a notable AhR activity compared with DMSO (Figure 6C). Fraction $\mathrm{Ci}$ induced a significant $(p \leq 0.05) \beta$-galactosidase activity starting from $0.5 \mu \mathrm{g} / \mathrm{mL}$. At $10-50 \mu \mathrm{g} / \mathrm{mL}$, the magnitude of activity of $\mathrm{Ci}$ was the same as $\beta$-naphthoflavone at its $\mathrm{EC}_{50}$-value. Sub-fraction F7 from $\mathrm{Ci}$ had the same effect already at $0.05-0.1 \mu \mathrm{g} / \mathrm{mL}$. A growing body of evidence indicates that $\mathrm{AhR} / \mathrm{ER} \alpha$ interactions greatly impact the gene expression and proliferative programs of estrogensensitive cancers cells. Research addressing this crosstalk showed repressive effects of ligands of AhR on ER $\alpha$ in the estrogen-induced proliferative responses in endometrium and breast cancer cells [16-19]. In respect with this, the activated AhR has been reported to increase the metabolism of E2 via the expression of cytochrome P450 enzymes (CYP1A1 and CYP1B1) [20] and to induce the ubiquitination and proteasomal degradation of ER $\alpha$ in rodent tumors and in ZR-75, T47D, and MCF-7 human breast cancer cells $[21,9]$. This degradation of ER $\alpha$ was significantly higher after co-treatment (co-activation) with E2 and 2,3,7,8-tetrachlorodibenzo- $p$-dioxin (TCDD) than after treatment with TCDD alone [9]. AhR can also inhibit ER-dependent transcriptional activities either by binding to the inhibitory xenobiotic response elements (iXRE) located in some ER-dependent promoters (promoter interference) or by the competition for a common pool of co-activators [8]. In addition, knockdown of AhR abrogates the repression of estrogen-dependent gene transcription in MCF-7 breast cancer and ECC-1 endometrial carcinoma cells [22] as well as in the development of colonic tumors in the cecum [23]. According to several reports, these repressive effects of AhR on cancer are mediated by the presence of exogenous ligands of AhR $[24,25]$. Our results show that some fractions of $E$. laurentii activated the AhR and thus, active constituents may be considered as exogenous ligands of this receptor. Given these repressive mechanisms of AhR on ER $\alpha$ signaling pathways and due to the coexistence of both receptors in estrogen-sensitive tissues including breast, uterus and 

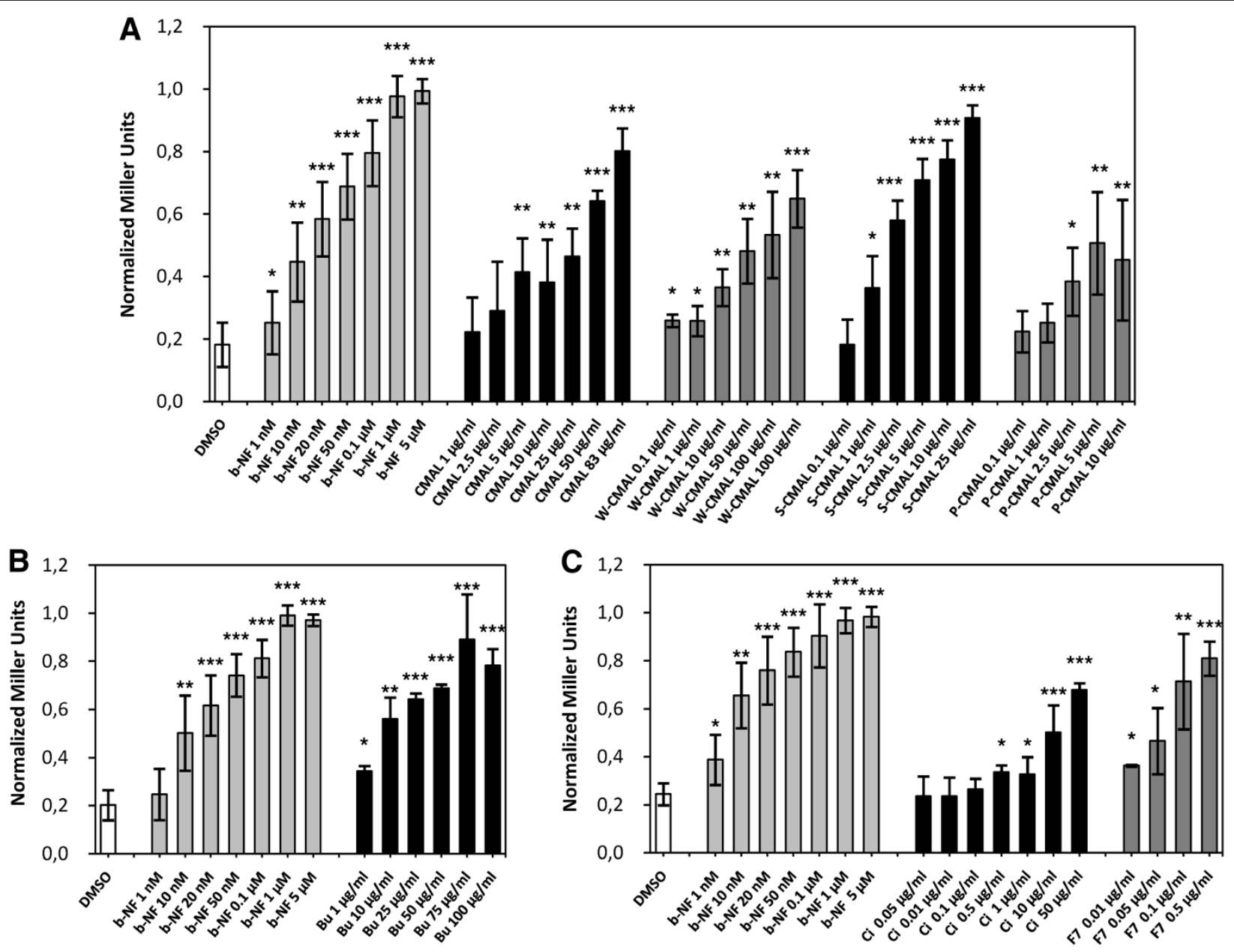

Figure 6 Normalized Miller Units of CMAL and its sub-fractions in the aryl hydrocarbon receptor yeast assay. DMSO: dimethyl sulfoxide, b-NF: $\beta$-naphthoflavone, A) CMAL: chloroform/methanol fraction of the methanol extract of aerial parts of Eriosema laurentii, W-CMAL: aqueous phase of CMAL, S-CMAL: non-soluble part of CMAL, P-CMAL: petroleum ether phase of CMAL, B) Bu: n-butanol fraction of W-CMAL, C) Ci: chloroform-isopropanol fraction of S-CMAL and F7: subfraction 7 of Ci. Data are expressed as mean \pm standard deviation of three independent experiments performed in duplicate. ${ }^{*} p \leq 0.05,{ }^{* *} p \leq 0.01$ and ${ }^{* * *} p \leq 0.001$ versus DMSO.

ovary our results suggest that the effect of E. laurentii on AhR could be of physiologic and anti-tumorigenic relevance. However, besides these anti-estrogenic effects of AhR, data in literature are quite conflicting regarding the implication of AhR in cancer promotion or prevention. It has also been related to cancer initiation or progression via the expression of CYP 450 enzymes (CYP1A1/2 and CYP1B1). The expression of CYP1A1 is part of negative feedback mechanisms regulating the AhR; by metabolization and agonist depletion, CYP1A1 prevents a constitutive activation of the AhR pathway. If this mechanism is impaired the AhR pathway is dysfunctional and toxic responses are the consequence [26]. Uno et al. observed in CYP1A1 knockout mice that although benzo[a]pyrene is metabolized by CYP1A1 to a carcinogenic epoxid form, in the absence of CYP1A1 acute benzo[a]pyrene toxicity is more fatal [27]. Nowadays, CYP1A1 is known to be predominantly important for detoxication of carcinogens and metabolic activation of dietary compounds with cancer preventive activity $[28,29]$ whereas CYP1B1 is implicated in the metabolic activation of procarcinogens causing DNA adducts formation [30]. In respect with this, up-regulation of CYP1A1 vs. CYP1B1 (detoxication/ procarcinogen activation) appears to be an indispensable precondition for tumor prevention. However, the underlying mechanisms that modulate this balance still remain unclear depending on the AhR agonists, cell context as well as co-regulators present in different cell types. Therefore, although several constituents of E. laurentii are AhR agonists, a final conclusion about their contribution to cancer prevention or progression is not possible, yet.

As far as the isolated compounds are concerned, 2'hydroxygenistein and lupinalbin $\mathrm{A}$ were found to be active in the AhR yeast assay (Figure 7 ). The $\mathrm{EC}_{50}$ value 


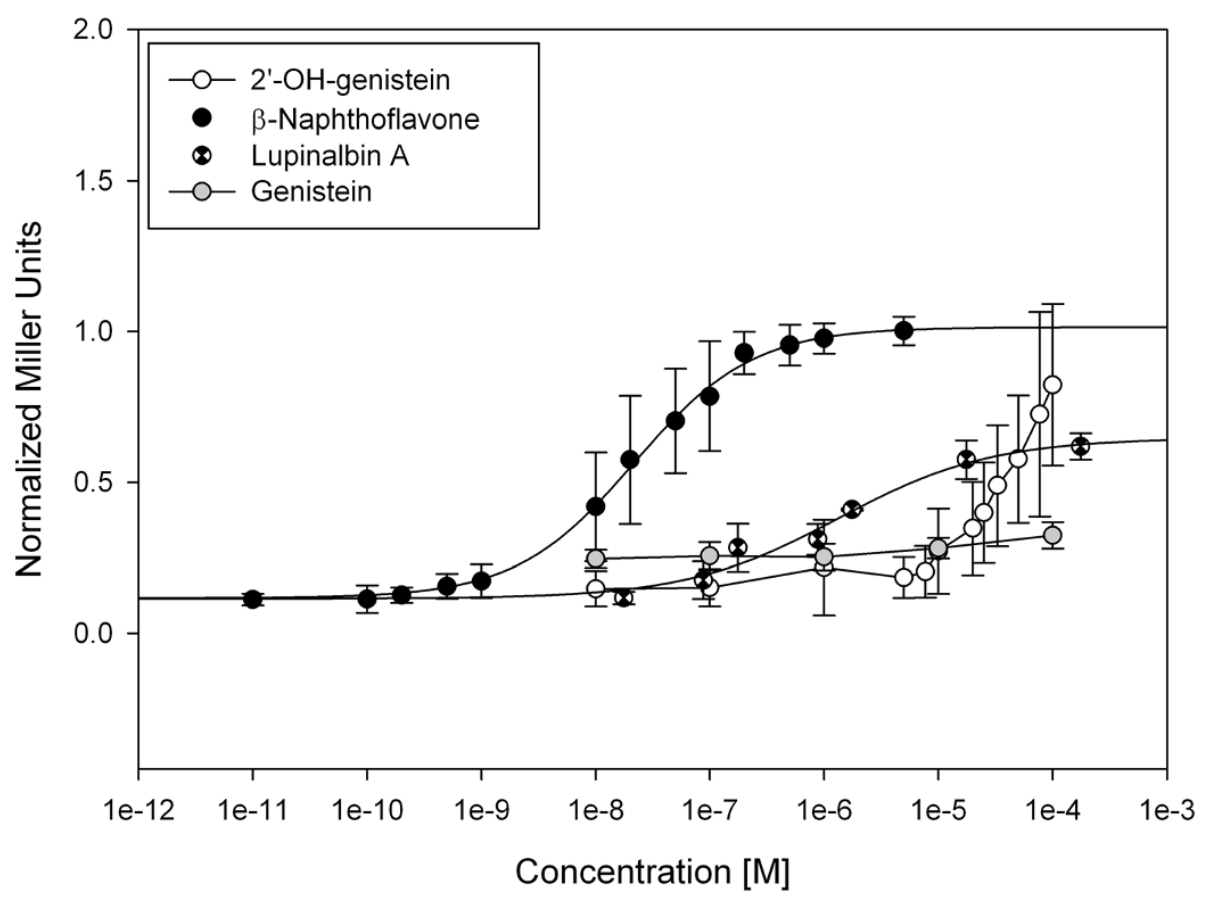

Figure 7 Dose-response curves of 2'-hydroxygenistein, lupinalbin A and genistein in the aryl hydrocarbon receptor yeast assay. Mean values of at least three independent experiments performed in duplicates are shown with standard deviations.

of lupinalbin A was $1.34 \mu \mathrm{M}$ while the one of 2'-hydroxygenistein was not determined because a saturation of the receptor was not achieved. To the best of our knowledge, these compounds have not been previously associated with any AhR activity. According to our results, genistein was not active, which is in agreement to previous data obtained with the same yeast system by Medjakovic and Jungbauer [5]. Thus, it appears that hydroxylation at C-2' of genistein as well as constraining ring $\mathrm{B}$ to the benzopyran core by an oxygen bridge are responsible for the observed AhR agonistic activity. Given the maximal efficacy, these compounds may be considered as partial agonists of AhR.

\section{Conclusions}

The activity-guided fractionation of the crude methanol extract of aerial parts of Eriosema laurentii lead to the identification of components with estrogenic and aryl hydrocarbon receptor agonistic activities. Genistein, 2'hydroxygenistein and lupinalbin $\mathrm{A}$, which were identified in or isolated from the most active fractions, were found to be full agonists of ER $\alpha$. Furthermore, we provide the first report of an agonistic activity of lupinalbin A and 2 '-hydroxygenistein towards the AhR, whereas genistein remained without effect at the AhR. The results enabled the deduction of structure-activity relationships for AhR agonistic activity between these compounds for the first time as well. Thus, the data presented in this study confirmed that these phytoconstituents contribute to the estrogenic and aryl hydrocarbon receptor agonistic activities of the extract of Eriosema laurentii and might partly account to the beneficial effects of the methanol extract in vivo.

\section{Abbreviations}

AhR: Arylhydrocarbon receptor; b-NF: $\beta$-naphthoflavone; E2: 17ß-estradiol; ERa: Estrogen receptor alpha.

\section{Competing interests}

The authors declare that they have no competing interests.

\section{Authors' contributions}

SBA participated in the study design, extraction and fractionation, performed the statistical analysis and drafted the manuscript. DN participated in the study design, helped to draft the manuscript and revised manuscript critically for important intellectual content. SM and AJ planned and carried out the yeast assays and contributed to the elaboration of the manuscript. MZ has acquired, analyzed and interpreted LC-MS data. HK recorded, analyzed and interpreted NMR data. LK conceived the study, has been involved in the fractionation of the extract and revised manuscript critically for important intellectual content. All authors read and approved the final manuscript.

\section{Acknowledgements}

Sylvin Benjamin Ateba has received an Ernst-Mach-Stipendium granted by the OeAD-Austrian Agency for International Cooperation in Education \& Research, financed by BMWF.

\section{Author details}

'Laboratory of Animal Physiology, Department of Animal Biology and Physiology, Faculty of Science, University of Yaounde I, P.O. Box 812, Yaounde, Cameroon. ${ }^{2}$ Department of Biotechnology, University of Natural Resources and Life Sciences Vienna, Muthgasse 18, A-1190 Vienna, Austria.

${ }^{3}$ Christian Doppler Laboratory for Receptor Biotechnology, Muthgasse 18, 
A-1190 Vienna, Austria. ${ }^{4}$ Department of Pharmacognosy, University of Vienna, Althanstrasse 14, A-1090 Vienna, Austria. Institut of Organic Chemistry, University of Vienna, Währingerstraße 38, A-1090 Vienna, Austria.

Received: 2 April 2014 Accepted: 5 August 2014

Published: 9 August 2014

\section{References}

1. Hidalgo IA, Chedraui PA, Morocho N, Ross S, San Miguel G: The effect of red clover isoflavones on menopausal symptoms, lipids and vaginal cytology in menopausal women: a randomized, double-blind, placebo-controlled study. Gynecol Endocrinol 2005, 21:257-264

2. Nagata C, Shimizu H, Takami R, Hayashi M, Takeda N, Yasuda K: Hot flushes and other menopausal symptoms in relation to soy product intake in Japanese women. Climateric 1999, 2:6-12

3. Wong WW, Lewis RD, Steinberg FM, Murray MJ, Gramer MA, Amato P, Young RL, Barnes S, Ellis KJ, Shypailo RJ, Fraley JK, Fisher JG, Smith EO: Soy isoflavone supplementation and bone mineral density in menopausal women: a 2-y multicenter clinical trial. Am J Clin Nutr 2009, 90:1433-1439.

4. Kuhnle GGC, Dell'Aquila C, Aspinall SM, Runswick SA, Mulligan AA, Bingham SA: Phytoestrogen content of beverages, nuts, seeds, and oils. J Agr Food Chem 2008, 56:7311-7315.

5. Medjakovic S, Jungbauer A: Red clover isoflavones biochanin A and formononetin are potent ligands of human arylhydrocarbon receptor. J Steroid Biochem Mol Biol 2008, 108:171-177.

6. Zhang S, Qin C, Safe SH: Flavonoids as aryl hydrocarbon receptor agonists/antagonists: effects of structure and cell context. Environ Health Persp 2003, 111:1877-1882.

7. Coumoul X: Dioxine et oestradiol: L'amour vache ou une histoire de «complexes». Med Sci (Paris) 2007, 23:701-702.

8. Safe S, Wormke M, Samudio I: Mechanisms of inhibitory aryl hydrocarbon receptor-estrogen receptor crosstalk in human breast cancer cells. J Mammary Gland Biol Neoplasia 2000, 5:295-306.

9. Wormke M, Stoner M, Saville B, Walker K, Abdelrahim M, Burghardt R, Safe S: The aryl hydrocarbon receptor mediates degradation of estrogen receptor alpha through activation of proteasomes. Mol Cell Biol 2003, 23:1843-1855.

10. Burkill HM: The Useful Plants of West Tropical Africa. Volume 3 Families $J-L$ including Leguminosae. Kew: Royal Botanic Garden; 1994.

11. Ateba SB, Njamen D, Medjakovic S, Hobiger S, Mbanya JC, Jungbauer A, Krenn L: Eriosema laurentii de Wild. (Leguminosae) methanol extract has estrogenic properties and prevents menopausal symptoms in ovariectomized wistar rats. J Ethnopharmacol 2013, 150:298-307.

12. Ateba SB, Simo RV, Mbanya JC, Krenn L, Njamen D: Safety profile and gender specific differences of a methanol extract of Eriosema laurentii (Leguminosae) in acute and subchronic (28 days) oral toxicity studies in Wistar rats. Food Chem Toxicol 2014, 65:27-32.

13. Selepe MA, Drewes SE, van Heerden FR: Total synthesis of the pyranocoumaronochromone lupinalbin H. Tetrahedron 2011, 67:8654-8658.

14. Yoo HS, Lee JS, Kim CY, Kim J: Flavonoids of Crotalaria sessiliflora. Arch Pharm Res 2004, 27:544-546.

15. Reiter E, Beck V, Medjakovic S, Mueller M, Jungbauer A: Comparison of hormonal activity of isoflavone-containing supplements used to treat menopausal complaints. Menopause 2009, 16:1049-1060

16. Buchanan DL, Sato T, Peterson RE, Cooke PS: Antiestrogenic effects of 2,3,7,8-tetrachlorodibenzo-p-dioxin in mouse uterus: critical role of the aryl hydrocarbon receptor in stromal tissue. Toxicol Sci 2000, 57:302-311.

17. Kitajima M, Khan KN, Fujishita A, Masuzaki H, Ishimaru T: Histomorphometric alteration and cell-type specific modulation of aryl hydrocarbon receptor and estrogen receptor expression by 2,3,7,8-tetrachlorodibenzo-p-dioxin and 17beta-estradiol in mouse experimental model of endometriosis. Reprod Toxicol 2004, 18:793-801.

18. Ohtake F, Fujii-Kuriyama Y, Kato S: AhR acts as an E3 ubiquitin ligase to modulate steroid receptor functions. Biochem Pharmacol 2009, 77:474-484.

19. Okino ST, Pookot D, Basak S, Dahiya R: Toxic and chemopreventive ligands preferentially activate distinct aryl hydrocarbon receptor pathways: implications for cancer prevention. Cancer Prev Res 2009, 2:251-256.

20. Tsuchiya Y, Nakajima M, Yokoi T: Cytochrome P450-mediated metabolism of estrogens and its regulation in human. Cancer Lett 2005, 227:115-124.
21. Marconett CN, Sundar SN, Poindexter KM, Stueve TR, Bjeldanes LF, Firestone GL: Indole-3-carbinol triggers aryl hydrocarbon receptor-dependent estrogen receptor (ER) alpha protein degradation in breast cancer cells disrupting an ERalpha-GATA3 transcriptional cross-regulatory loop. Mol Biol Cell 2010, 21:1166-1177.

22. Labrecque MP, Takhar MK, Hollingshead BD, Prefontaine GG, Perdew GH, Beischlag TV: Distinct roles for aryl hydrocarbon receptor nuclear translocator and ah receptor in estrogen-mediated signaling in human cancer cell lines. PLoS One 2012, 7:e29545.

23. Kawajiri K, Kobayashi Y, Ohtake F, Ikuta T, Matsushima Y, Mimura J, Pettersson S, Pollenz RS, Sakaki T, Hirokawa T, Akiyama T, Kurosumi M, Poellinger L, Kato S, Fujii-Kuriyama Y: Aryl hydrocarbon receptor suppresses intestinal carcinogenesis in ApcMin/q mice with natural ligands. Proc Natl Acad Sci USA 2009, 106:13481-13486.

24. Abel J, Haarmann-Stemmann T: An introduction to the molecular basics of aryl hydrocarbon receptor biology. Biol Chem 2010, 391:1235-1248.

25. Feng $S$, Cao Z, Wang X: Role of aryl hydrocarbon receptor in cancer. Biochim Biophys Acta 1836, 2013:197-210.

26. Kerger BD, Leung HW, Scott P, Paustenbach DJ, Needham LL, Patterson DG $\mathrm{Jr}$, Gerthoux PM, Mocarelli P: Age- and concentration-dependent elimination half-life of 2,3,7,8-tetrachlorodibenzo-p-dioxin in Seveso children. Environ Health Perspect 2006, 114:1596-1602.

27. Uno S, Dalton TP, Derkenne S, Curran CP, Miller ML, Shertzer HG, Nebert DW: Oral exposure to benzo[a]pyrene in the mouse: detoxication by inducible cytochrome P450 is more important than metabolic activation. Mol Pharmacol 2004, 65:1225-1237.

28. Androutsopoulos VP, Tsatsakis AM, Spandidos DA: Cytochrome P450 CYP1A1: wider roles in cancer progression and prevention. BMC Cancer 2009, 9:187.

29. Hosoya T, Harada N, Mimura J, Motohashi H, Takahashi S, Nakajima O, Morita M, Kawauchi S, Yamamoto M, Fujii-Kuriyama Y: Inducibility of cytochrome P450 1A1 and chemical carcinogenesis by benzo[a]pyrene in AhR repressor-deficient mice. Biochem Biophys Res Commun 2008, 365:562-567.

30. Uno S, Dalton TP, Dragin N, Curran CP, Derkenne S, Miller ML, Shertzer HG Gonzalez FJ, Nebert DW: Oral benzo[a]pyrene in Cyp1 knockout mouse lines: Cyp1A1 important in detoxication, Cyp1B1 metabolism required for immune damage independent of total-body burden and clearance rate. Mol Pharmacol 2006, 69:1103-1114.

doi:10.1186/1472-6882-14-294

Cite this article as: Ateba et al:: Lupinalbin $A$ as the most potent estrogen receptor a- and aryl hydrocarbon receptor agonist in Eriosema laurentii de Wild. (Leguminosae). BMC Complementary and Alternative Medicine 2014 14:294.

\section{Submit your next manuscript to BioMed Central and take full advantage of:}

- Convenient online submission

- Thorough peer review

- No space constraints or color figure charges

- Immediate publication on acceptance

- Inclusion in PubMed, CAS, Scopus and Google Scholar

- Research which is freely available for redistribution 